\title{
Value Below Reference Range
}

National Cancer Institute

\section{Source}

National Cancer Institute. Value Below Reference Range. NCI Thesaurus. Code C78801.

Reported values below the typical or expected range. 